\title{
Erratum zu: Journalistisches Handeln in der Skandalberichterstattung
}

\section{Erratum zu:}

N. Wehlisch, Journalistisches Handeln in der

Skandalberichterstattung, https://doi.org/10.1007/978-3-658-36135-8

Aufgrund eines technischen Fehlers wurde das Abstract in englischer Sprache sowie die Information zur genderneutralen Sprache nicht eingefügt. Dies wurde nun korrigiert. 